\title{
Review the Progress of the Compensation System for Ecological and Environmental Damage in China
}

\author{
Hongxin Guo \\ Law School, Zhongnan University of Economics and Law, Wuhan, China
}

Email address:

ghxlaw@126.com

To cite this article:

Hongxin Guo. Review the Progress of the Compensation System for Ecological and Environmental Damage in China. International Journal of Law and Society, Vol. 3, No. 4, 2020, pp. 189-194. doi: 10.11648/j.ijls.20200304.15

Received: November 9, 2020; Accepted: November 23, 2020; Published: December 4, 2020

\begin{abstract}
The establishment of the Compensation System for Ecological and Environmental Damage is the key implementation content of the "Ecological Civilization" strategies in China. The purpose of the Ecological and Environmental Damage Compensation System is to break the dilemma of "environmental priceless, no claim for compensation", "corporate pollution, government paying". It is a feasible method to comprehensively remedy China's damaged environment by imposing negotiation and litigation against liable parties that engaged in environmental pollution and ecological destruction. The reform began in 2015. In recent years, the reform has been trailed in the mainland of China. Some provinces have promulgated their local version of an implementation plan and formed regulations about it. Many cases have been done in practice. This paper purports to introduce the practice of the Ecological and Environmental Damage Compensation System in China, analyze the problems disclosing from the trailed implementation, such as insufficient judicial support for claimants, absence of procedural legislation and unclear relationship with other public interest litigation. Meanwhile, the paper also proposes three suggestions to improve the Ecological and Environmental Damage Compensation System: restoration priority principle in negotiation; limited applicable scope; procuratorates' performing legal supervision duties.
\end{abstract}

Keywords: Ecological and Environmental Damage, The Reform Plan, Negotiation, Litigation

\section{Introduction}

It has been pointed out that China's spectacular economic growth is at the cost of environmental pollution. The ecological and environmental damages (abbreviation: EED) have become an unavoidable environmental issue facing China. Although the legal system has been trying to fulfill the "polluter responsibility" principle effectively, the EED is still occurring. There are legislative gaps in current law to address this issue. The existing environmental liability mechanisms is insufficient to compensate for EED. The governments have to undertake the clean-up and remedial work of the damaged ecology and environment. An ecological compensation model for Liuxi River Basin based on emission rights shows that the ecological compensation amount for Conghua in 2017 is determined to be 33.821 billion Yuan, accounting for $84.5 \%$ of the district's total GDP. [1] It's a very big burden for the government.

To alleviate the deterioration of the ecological environment by holding offenders responsible for environmental pollution and ecological destruction and restore the damaged ecological environment, China has brought a crucial institutional innovation. Pilot Plan for Reform of the Ecological Environment Damage Compensation System (abbreviation: Pilot Plan) was promulgated by the central government ${ }^{1}$ in 2015 . Seven provinces were selected for plan piloting in 2016. By summarizing the practices (including specific system design, typical cases, and practical experience) at the pilot stage, the central government formulated the Reform Plan of the Ecological Environmental Damage Compensation System (abbreviation: Reform Plan) in 2017 to expand the scope of the pilot to the whole nation. [2] After the Reform Plan was carried out nationwide in 2018, all provinces have carried out this system actively.

\footnotetext{
${ }^{1}$ General Office of the Central Committee of the Communist Party of China (General Office, CCCPC) and General Office of the State Council promulgated the Pilot Plan jointly.
} 


\section{Practice of the EED Compensation System}

By April of 2020, eighteen provinces in China have promulgated their local versions of the "Implementation Plan for the reform of the Ecological Environment Damage Compensation System" (hereinafter referred to as the "Implementation Plan"), which are based on the Reform Plan, combining the local features and practice needs. Meantime, they have been actively seeking suitable and typical cases about ecological environment damage compensation to claim for restoration/compensation.

The Ministry of Ecology and Environment organized the "Consultation and Selection of Ten Typical Cases for Ecological and Environmental Damage Compensation" in November 2019, and announced 20 excellent candidate cases. Together with other typical cases collected in this research, a total of 60 cases are used as research samples in this paper. Through these samples we can see the whole practices of the EED Compensation System in China. According to this practice, the reform has the following characteristics.

\subsection{Wide Scope of the Claimants}

The reform of the EED Compensation System is built on the theory of ownership in the continental law system.

According to articles 9-10 of the Chinese Constitution that "natural resources belong to the state", China implements a state ownership system for natural resources. [3] The relevant laws stipulate that the State Council exercises the ownership of natural resources on behalf of the state. ${ }^{2}$

The Pilot Plan authorized the pilot provincial governments to represent the country to initiate negotiations or litigation on EED. [4] In practice, only in three of 30 cases the claimants were the Provincial People's Governments. In the other 9 cases, the claimants were Provincial and Municipal Environmental Protection Bureau. The other one was the Provincial Marine Fisheries Bureau.

The Reform Plan expands the scope of claimants from provincial governments to municipal and prefectural governments. Among the 30 negotiation cases, the Municipal Ecological Environment Bureau participated in 14 cases, accounting for nearly half of the number of cases. Six cases were negotiated by the District Ecological Environment Bureau. Only three cases were negotiated by the Provincial Ecological Environment Bureau. In other cases, the claimants were the relevant institutions of local governments.

\subsection{Monetary Compensation Be the Main Liability}

The EED Compensation System focuses on remedies for environmental harm, trying to solve the dilemma of "polluted by the enterprises, suffered by the public, paid by the government". [5] The purpose of the EED Compensation System is to provide a new instrument to compensate for the

2 In practice, the ownership may actually be exercised by specific departments of the State Council or local people's governments. injured ecological environment and natural resources. To repair the ecological environment was stated as a principle in all the Pilot Plan and Reform Plan. Only when the damage could not be repaired, monetary compensation can be used as a subsidiary. ${ }^{3}$

In practice, 60 sample cases show that monetary compensation was the first choice, not distinguishing whether the damage can be remedied. The management of collection and application of these compensations were very different in pilot provinces. Except for a few provinces such as Shandong and Hunan that had issued special fund management measures, there were no specific regulations on the management and use of funds in the regional pilot places. From the survey, we found that the compensation funds were difficult to be adapted to the needs of ecological environment restoration.

After the implementation of the Reform Plan, the management of compensation became more standardized. Sorting out 33 sample cases in this stage, we found that the management of compensation funds for ecological environmental damage was roughly divided into two categories. One was to take the compensation fund as non-tax revenue of the government and turn it over to the national treasury. The other was to submit a special account to the administrative department of the government. Currently, the Municipal Bureau of Ecology and Environment and the Municipal Ministry of Finance were the main ones in charge of these accounts.

\subsection{Negotiating Before Litigating}

The Claimants can claim for restoration/compensation through negotiation or litigation. In the Pilot Plan, negotiation is not a necessary procedure for the claimants. The Reform Plan makes it clear that negotiation is a precondition for the claimants to bring an EED case into the courts. That means only when the negotiation between the claimants and the liable parties failed to reach an agreement, the claimants can resort to judicial relief.

Among the 60 sample cases, 43 cases were negotiated, accounted for about $70 \% .34$ cases reached an agreement in the end, accounting for $80 \%$ of cases through consultation procedures. There were 9 cases that turned into litigation for failing to reach an agreement by negotiation. One case was solved by negotiating and litigating all. In one case, the agreement has been reached before the procuratorate initiated civil public interest litigation. Some cases realize restoration/compensation by other methods. ${ }^{4}$

From 2018, with the Reform Plan carried out, negotiation became the first step in practice. There were 30 cases in 33 sample cases ended by negotiation. Only 7 cases failed to reach agreements. The number of cases initiated to the litigation was down.

Additionally, to improve the effectiveness of the negotiated agreement, the Reform Plan states the agreement can be

\footnotetext{
3 See Pilot Plan and Reform Plan, part II-2.

4 In some cases the obligor made the compensation actively.
} 
jointly applied for judicial confirmation to the court. ${ }^{5}$ In some provinces, after successful negotiation, the settlement was sent to the Court for judicial confirmation.

\subsection{Positive Procuratorates}

Before the reform of the EED Compensation System, China has set up public interest litigation to cope with ecological and environmental damages. The 2014 Environmental Protection Law of the People's Republic of China (abbreviation: EPL) and 2017 Civil Procedure Law of the People's Republic of China (abbreviation: CPL) allow qualified social organizations to take "acts of polluting or damaging the environment that has harmed the public interest." ${ }^{6}$ In the past few years, Chinese procuratorates have gradually taken a more active role in the environment protection by implying some judicial interpretations. ${ }^{7}$ According to these laws, regulations and policy documents, social organizations, procuratorates, and people's governments can bring a lawsuit on EED.

At the stage of the Pilot Plan implementation, the procuratorates just paid more attention to initiating civil public interest litigation. After the implementation of the Reform Plan, the procuratorates have begun to play a more active role during the negotiation process. Among the negotiating cases, some claimants invited the local procuratorates to take part in the negotiation process. In some cases, the municipal procuratorate sent the procuratorial suggestion to the municipal government to speed up the start of the ecological environment damage compensation procedure after clarifying the liable parties. ${ }^{8}$ [6]

There were 4 environmental public interest lawsuits initiated by the procuratorate. In one of them, the procuratorate withdrew prosecution by reconciling with the compensation obligor, after the negotiation agreement was reached. In another case, the litigation was initiated by the procuratorate after the agreement was reached between the obligor and claimant to supervise the obligor to perform the settlement.

\section{Evaluating the Reform Practice}

The reform of the EED Compensation System has been in operation for four years since the Pilot Plan was officially launched in December 2015. Most provinces have been

\footnotetext{
5 The "Reform Plan", part VI-4.

6 Environmental Protection Law of the People's Republic of China, Art. 58; Civil Procedure Law of the People's Republic of China, Art. 55.

7 In Jul. 2, 2015, the Supreme People's Ct. and the Supreme People's Procuratorate promulgated Plan for the Pilot Project of Reform of Instituting Public Interest Litigations by the Procuratorial Organs. Then Notice of the Supreme People's Court on Issuing the Measures for the Implementation of the Pilot Program of Trial by People's Courts of Public Interest Litigation Cases Instituted by People's Procuratorates was promulgated by the Supreme People's Ct. and the Supreme People's Proc. in Feb. 25, 2016, which effective in Mar. 1, 2016. ${ }^{8}$ According to Organic Law of the People's Procuratorates of the People's Republic of China, the Procuratorates can supervise and urge the local governments (and their departments or institutions) to perform their duties through procuratorial suggestions.
}

vigorously pushing forward in promulgating local versions of the Implementation Plan, identifying cases and liable parties, assessing damages, taking actions to negotiate, and so forth. Overall, the main components of the EED compensation system have been clear. Corresponding supporting systems have also been formulated. As a new tool to solve the EED, it is still immature.

\subsection{Insufficient Judicial Support for Claimants}

With growing economic welfare, the demand for environmental quality is increasing in China. The law has to respond to these new demands. The concept of "victims" should be interpreted broadly to include both humans and nature for the damage to the environment, which has been accepted by the law in China. [7] But traditional tort law was insufficient to compensate for ecological damage.

The Environmental Protection Law (EPL), as the basic statute in the field of environmental protection in China, states that: "A unit that has caused an environmental pollution hazard shall be bound to eliminate it and make compensation to the unit or individual that suffered direct losses." [8] That means environmental liability introduces a strict liability principle, without violating any regulation. The new Tort Liability Law (TLL), adopted in 2009, contains rules on environmental liability and opts for a strict liability regime. The environmental damage should be compensated. However, it is unclear whether the environmental liability rules in civil law also cover ecological damage. To determine the extent to which ecological damage needs to be restored and compensated, reference should be made to specific environmental statutes. [7] But now only the Marine Environmental Protection Law (MEPL) explicitly mentions ecological damage is a compensable tort, concerning the release of oil into the marine environment. The range of compensation components is not clear in the litigation, not to mention the assessment standards which can be used as a determination for restoring the damage.

Another question is who has the right to ask for remedies on behalf of the environment. As mentioned above, the National People's Congress has authorized legally prescribed departments and qualified social organizations and the People's Procuratorate to institute civil public interest litigation in the courts when they find conducts that undermined the protection of the ecological environment and resources. As to the government, theoretically, the state ownership of natural resources can be regulated by property law. [9] But the ecosystem services and other types of natural resources can not be included in the national property sequence. The "private interest protection" can not be the foundation for the government to take claim action in EED cases.

The reform of the EED Compensation System is utilizing the protection mechanism of the property rights and interests of the natural resource owners under the current legal regime. [10] Governments are empowered to initiate litigation on behalf of the national interest. Based on the state ownership of natural resources, the government becomes the interest 
representative and the claimant is self-consistent and reasonable. At present, China's relevant laws only authorize the State Council to exercise state ownership of natural resources on behalf of the state. The authorization needs more legitimacy by the National People's Congress (NPSC) and its Standing Committee through congressional authorization in the future.

\subsection{Absence of Procedural Legislation}

Local governments of China have created a more holistic scope of claimants, fulfilled negotiation before litigation and set up a special account for compensation. But the procedural rules related to the EED Compensation System are still insufficient and immature.

The State Council authorized provincial and municipal people's governments to act as the claimant in the cases of compensation for EED. The provincial and municipal people's governments took actions depending on their agencies. So the governmental agencies interwine the national interests coming from the administrative and the public interests representative coming from the natural resources' ownership at the same time. Both negotiation and litigation of EED claimed for civil liability operated under the Civil Procedure Law. There were no clear rules on how the governments carry out the negotiation on EED as the identity of the specific compensatory rights owner.

Due to the negotiation, the absence of relevant adjudication rules was also obvious. According to the Reform Plan, the settlement reached after successful negotiation can be sent to the Court for judicial Confirmation. However, the current judicial confirmation just applies to a specific agreement that is reached between the mediation of the "People's Conciliation Committee" and other civil parties. ${ }^{9}$

As for the new litigation of EED, there is no provision in China's laws, except for a judicial interpretation promulgated in 2019 to guide the courts correctly trying cases on compensation for damage to the ecological environment. [11]

\subsection{Unclear Relationship with Other Public Interest Litigation}

As mentioned above, legislation has begun to encourage space for public interest litigation to cope with EED. There are two types of public interest litigation in China: civil public interest litigation and administrative public interest litigation. After a few years of development, the public interest litigation has still not been the main channel for effectively remedying the damaged public interests of the ecological environment. [10]

9 Judicial confirmation is a legal procedure stipulated in People's Mediation Law of China. After a mediation agreement is reached upon mediation by a people's mediation commission, when necessary, the parties concerned may jointly apply to the people's court for judicial confirmation within 30 days after the mediation agreement becomes effective, and the people's court shall examine the agreement and confirm its effect in a timely manner. After the people's court confirms the effect of the mediation agreement, if one party concerned refuses to perform or fails to fully perform it, the other party may apply to the people's court for enforcement. (People's Mediation Law, article 33)
The Reform Plan empowered governments to initiate litigation on behalf of the national interest. As either NGOs or the procuratorates can bring the public interest lawsuit against the same defendants on behalf of public interest, the relationship between them should be clarified. The Reform Plan only points out that they do not affect each other, but there is no definite guideline on how to link and coordinate the systems for positive interaction in theory and practice.

\section{Improvement of the EED Compensation System}

The EED Compensation System is to be a new regular type of environmental damage remedy system. The progress will initiate legislation and revision work about the EED Compensation System to establish basic rules to legalize the reform soon. As part of the entire accountability system, the EED Compensation System should make clear the negotiation rules and the role of different subjects in initiating public interest litigation. A stable and compatible accountability system to restore the damaged ecological environment requires the EED compensation system to improve as follows.

\subsection{Restoration Priority Principle in Negotiation}

Even though the traditional remedy for damages is monetary compensation, as for the EED, the most effective remedy should be restitution. The goal of the EED Compensation System is also to encourage the obligor to repair the damaged ecological environment. To make sure that someone will take actual removal actions and remedial actions immediately, the restoration priority principle should be applied in the whole negotiation for the EED. The obligor of compensation shall repair the damaged environment first, and may entrust a third party to repair it if he has no repair ability. Claimants should examine the extent to which these remedies are applied. If the damage is irreparable and it is necessary to pursue legal responsibility, the claimants can bring a lawsuit for monetary compensation.

The scope of monetary compensation should be limited in the range of the remedy costs for EED, emergency treatment costs, investigation and appraisal of compensation for EED, and so on.

Monetary compensation for EED should be applied to restore the damaged ecology and environment. The litigation should stipulate the monetary compensation management as "special funds appropriate". When the money is imposed as non-tax revenue of the government to the national treasury, it is difficult to be used to repair certain damage. Due to China's financial management system, the management of the national treasury is very strict. If a remedy project is to be implemented, it needs to be included in the budget in advance. The long and complicated procedures are used even to exceed the restoration cycle. Lack of the "special funds appropriate" regulation, the compensation funds may be diverted for other purposes by some local governments, which would not be used to remedy the environment. [12] 


\subsection{Limited Applicable Scope}

According to the environmental administrative law enforcement in China, administrative orders, administrative penalties, and administrative coercion can be adopted to remedy the damages when the EED has already occurred. [13] But the environmental administrative penalty mechanism cannot fully achieve the principle of "polluter pay" or effectively deter the violators for lacking the substantial binding force of admonition penalty, the low amount of monetary penalties, and poor application of cease, desist, close penalties. [10]

The reform of the EED Compensation System has to claim "compensation" from enterprises or individuals who damage the environment on behalf of the people. As a civil liability, it should be a step method to claim for the compensation. A violation of a relevant regulation should be a condition, and the violation should be restricted with labels like "large," "severe" and "key area". The limited applicable scope can be used to make sure that the administrative agency has tried its best to claim for the EED costs.

\subsection{Procuratorates Performing Legal Supervision Duties}

The procuratorate is a legal supervision department stipulated by the Constitution in China. The litigation has empowered procuratorates to institute environmental public interest litigation (including administrative public interest litigation and civil public interest litigation) in the past few years. The purpose of civil environmental public interest litigation initiated by the Procuratorates is the same as that by the NGOs and the governments for EED. Only if there is no qualified authority or social organization or the qualified authority or social organization does not file a lawsuit, may the procuratorate file a lawsuit with the people's court. If the qualified authority or social organization files a lawsuit, the people's procuratorate may support the filing of a lawsuit. [14] That means it would be better for the Procuratorates to play the role of the supporter. [15]

As for compensation cases of EED, the Procuratorates don't have to take part in the negotiation. If the government claimants are unwilling to take negotiation with the liable parties, the procuratorates can supervise and urge the local governments to take actions by offering procuratorial suggestions or to initiate administrative public interest litigation. In other words, the procuratorates' role should be a supervisor in the EED Compensation System.

\section{Conclusion}

The establishment of the Compensation System for EED will be a milestone in China's environmental regulation. Relating to the stability and compatibility of the entire accountability system, it must work together with the traditional administrative law enforcement, environmental public interest litigation, and other means. Although there are some regulations and judicial interpretations about the main components of the EED Compensation System, as a comprehensive system, it is necessary to establish basic rules.
To initiate legalization or revision procedures, it depends on the way to amend the existing law or enact the new law. ${ }^{10}$ [16-18] No matter what path is taken, the issues raised in this paper should be clarified.

\section{References}

[1] Pan, Bole, et al. "An Ecological Compensation Model for Liuxi River Basin Based on Emission Rights." Journal of Management and Sustainability, vol. 9, no. 2, 2019, p. 128-135.

[2] Reform Plan of the Ecological Environment Damage Compensation System] (promulgated by St. Council, Dec. 17, 2017).

[3] Constitution of the People's Republic of China, promulgated by National People's Congress, 2018 Amendment.

[4] Pilot Plan for Reform of the Ecological Environment Damage Compensation System, promulgated by St. Council, Dec. 3, 2015.

[5] Decision of the Central Committee of the Communist Party of China on Several Major Issues of Comprehensive Deepening Reform, promulgated by CPC. Committee, Nov. 12, 2013.

[6] Organic Law of the People's Procuratorates of the People's Republic of China, promulgated by Nat'l People's Cong., July 5, 1979, effective Jan. 1, 1980, amended Oct. 26, 2018.

[7] Michael G. Faure and Liu Jing, "Compensation for Environmental Damage in China: Theory and Practice", PACE ENVTL. L. REV. (2014) 31: 1, pp. [i]-309.

[8] Environmental protection law of the People's Republic of China (2014). the National People's Congress.

[9] Cui Jianyuan, "Orientation and Improvement of State-Ownership of Natural Resources", Faxue Yanjiu, 4 (2013), pp 66-68.

[10] Weiyu Wu, "The Reform of the Compensation System for Ecological and Environmental Damage in China: Natural Resources, Environmental Enforcement, and Legislation", 60 NAT. Resources J. 63 (2020), pp 63-102.

[11] Several Provisions of the Supreme People's Court on the Trial of Cases on Compensation for Damage to the Ecological Environment (for Trial Implementation), promulgated by Supreme People's Court Jun 4, 2019, effective Jun. 5, 2019.

[12] Luo Guangqian: "Who is in charge of the compensation fund for ecological environment damage? How", China Ecological Civilization, 4 (2018), pp 32-36.

[13] Zhang Bao, "An analysis of the applicable relationship between government civil claim and supervision power in ecological environment damage relief", FaXue Luntan, 3 (2017), pp $14-21$

[14] The Civil Procedure Law of the People's Republic of China promulgated by Standing Committee of the National People's CongressSupreme People's Court, amended in 2017.

\footnotetext{
${ }^{10}$ Most of the Chinese scholars, policymakers, and reform implementers advocate legalize the reform. But the opinions about the solutions are different in amending the existing law or enacting the new law.
} 
[15] Zhang Zitai and Wu Weiyu, "Research on Legislation of Compensation for Eco-Environment Damage in China", Envtl. Protection, 5 (2018), PP 25-30.

[16] Ma Teng, "The Construction of Ecological Environment Tort Liability System in China", Fashang Yanjiu, 2 (2018), PP 114-123.
[17] Zhao Xiaojiao, "The Legislation of Compensation for Ecological Environment Damage in China: Modes and Difficulties", Journal of northeastern University (social science), 5 (2020), PP81-89.

[18] Zhang Zitai and Li Chenguang, Some Problems about Legislation of Compensation for the Ecological Damage in China”, Nanjing Shehui Kexue, 3 (2018), PP94-99. 